
\title{
ZS Research Square \\ Topographical effects on the timing of growing season in alpine grasslands
}

Xiaobin Hua ( $\square$ Xiaobin.Hua@lincoln.ac.nz )

Lincoln University https://orcid.org/0000-0001-8443-5068

Ralf Ohlemüller

University of Otago

Pascal Sirguey

University of Otago

\section{Research Article}

Keywords: Alpine grassland, MODIS, NDVI, Phenology, Topography

Posted Date: May 14th, 2021

DOl: https://doi.org/10.21203/rs.3.rs-441072/v1

License: (1) This work is licensed under a Creative Commons Attribution 4.0 International License.

Read Full License 


\section{Topographical effects on the timing of growing season in alpine}

\section{grasslands}

Xiaobin Hua ${ }^{1,3 *}$ * Corresponding author (Xiaobin.Hua@lincoln.ac.nz, +64 210415796 ,

ORCID: 0000-0001-8443-5068)

Ralf Ohlemüller ${ }^{1}$, (ralf.ohlemuller@otago.ac.nz)

Pascal Sirguey², (pascal.sirguey@otago.ac.nz)

1 School of Geography, University of Otago, New Zealand

2 School of Surveying, University of Otago, New Zealand

3 School of Landscape Architecture, Lincoln University, New Zealand

\section{Abstract}

Context: It is important to understand the responses of alpine vegetation to recent

anthropogenic climate change. The mountainous landscapes with high climatic heterogeneity are good locations to investigate the effects of microclimatic variation on alpine ecosystems.

Objectives: a) To what degree do topographical factors (aspect and elevation) affect the timing of growing season in alpine grasslands? b) Are these topographical effects different on alpine and non-alpine grasslands?

Methods: We extracted five annual growth phenology indices (Start, End, Length, Peak and Peak-NDVI) in alpine and non-alpine grasslands in the Clutha river catchment, New Zealand with a near-daily NDVI (Normalized Difference Vegetation Index) dataset through 16 years (2001-2016). The shifting rates of these phenology indices were quantified with two topographical factors (aspect and elevation).

Results: The start of season was delayed by 7.5, 5.1 and 3.7 days per $100 \mathrm{~m}$ higher of elevation in three grassland types (Alpine, Tall Tussock and Low Producing) respectively, and the end of season was advanced by $1.7,1.3$ days and delayed by 0.3 days per 10-degreesouth on slopes individually. The longer season length was observed at lower elevation and on north-facing (sunny) slopes. The later season peak occurred at higher elevation and on north-facing slopes. The lower peak NDVI was detected at the higher elevation.

Conclusions: In the studied grasslands, aspect and elevation were correlated to different phenological indices, and they affect phenology independently. The topographical effects are more pronounced in alpine ecosystems at the elevation above 1,300 $\mathrm{m}$ than in non-alpine ecosystems at lower elevation.

Key words: Alpine grassland, MODIS, NDVI, Phenology, Topography.

\section{Acknowledgement}

This study is sponsored by Miss E. L. Hellaby Indigenous Grasslands Research Trust granted to Xiaobin Hua in 2016. 


\section{Topographical effects on the timing of growing season in alpine 2 grasslands}

\section{Abstract}

Context: It is important to understand the responses of alpine vegetation to recent anthropogenic climate change. The mountainous landscapes with high climatic heterogeneity are good locations to investigate the effects of microclimatic variation on alpine ecosystems. Objectives: a) To what degree do topographical factors (aspect and elevation) affect the timing of growing season in alpine grasslands? b) Are these topographical effects different on alpine and non-alpine grasslands?

Methods: We extracted five annual growth phenology indices (Start, End, Length, Peak and Peak-NDVI) in alpine and non-alpine grasslands in the Clutha river catchment, New Zealand with a near-daily NDVI (Normalized Difference Vegetation Index) dataset through 16 years (2001-2016). The shifting rates of these phenology indices were quantified with two topographical factors (aspect and elevation).

Results: The start of season was delayed by 7.5, 5.1 and 3.7 days per $100 \mathrm{~m}$ higher of elevation in three grassland types (Alpine, Tall Tussock and Low Producing) respectively, and the end of season was advanced by $1.7,1.3$ days and delayed by 0.3 days per 10 -degreesouth on slopes individually. The longer season length was observed at lower elevation and on north-facing (sunny) slopes. The later season peak occurred at higher elevation and on north-facing slopes. The lower peak NDVI was detected at the higher elevation.

Conclusions: In the studied grasslands, aspect and elevation were correlated to different phenological indices, and they affect phenology independently. The topographical effects are more pronounced in alpine ecosystems at the elevation above 1,300 $\mathrm{m}$ than in non-alpine ecosystems at lower elevation.

Key words: Alpine grassland, MODIS, NDVI, Phenology, Topography.

\section{Introduction}

Montane landscapes are characterised by their high environmental heterogeneity over a small spatial extent. With this characteristic mountainous landscapes facilitate high levels of biodiversity and a high ecological significance (Testolin et al. 2020; Verrall and Pickering 2020). Alpine ecosystems, which often live at mountains, are expected to be highly vulnerable to the impacts of recent anthropogenic climate change (Rogora et al. 2018; Gottfried et al. 2012). It is important to understand the functional responses of vegetation to the changing climatic conditions in these topographically complex environments (Opedal et al. 2015; Dufour et al. 2006). The high topographical and climatic heterogeneity in montane areas are good 
locations to investigate the effects of microclimatic variation on the key life-cycle attributes in alpine vegetation ecosystems.

Researches showed that topographical features are substantial gradients which affect the growing season of alpine species. For example, the regional difference in slope and aspect affects the timing and duration of snow cover (Tennant et al. 2017; Redpath et al. 2018), and in turn affects the timing of growth and ecological processes in alpine vegetation. A European conifer in the Swiss Alps exhibited a delayed needle and stem growth with increasing elevation (Moser et al. 2010). A shorter growing season was observed in a montane forest in Colorado, the US as elevation increases or in the north-facing (shaded) sites (Barnard et al. 2017). In the Australian Alps, the start of growth season in alpine species in recent years (2000-2014) was detected to be sensitive to elevation change (Thompson and Paull 2017). It has been widely documented that alpine plants can shift the timing of biological processes to adapt the topographical variances in a montane environment.

There are two key effects of climate change on vegetation: range shifting and phenology changing. An upward trend in range shifting of plant species has been observed in many alpine ecosystems around the world, and these shifts were in the same direction that is congruent with the direction expected under a global warming condition (Chen et al. 2011; Telwala et al. 2013). Mountainous species have moved upwards over the last 100 years as a response to follow the shifted analogous climate condition (Lenoir et al. 2008; Scherrer and Korner 2010). The upwards shifting, as a result, may lead alpine species to run out of their habitats when they reach mountain summits. However, other studies argue that the high topographical heterogeneity in montane landscapes can offer diverse climate conditions for alpine species: Instead of moving uphill, shifting sideways to a different aspect of slope, in order to find analogous climate conditions, is also possible (Spasojevic et al. 2013; You et al. 2018). A study in the alpine ecosystems on shaded slopes at high elevation $(1,370-1,800 \mathrm{~m})$ in New Zealand showed that microclimate factors can shape the distribution of alpine plants which adapted to specific environmental drivers (Bickford et al. 2011). Is moving up mountains the same as moving around mountains for alpine vegetation? To answer this question, we aim to tackle the relationship between topography and growth phenology in alpine ecosystems.

In this study, we used the near daily MODIS (Moderate-resolution Imaging Spectroradiometer) NDVI (Normalized Difference Vegetation Index) images through 16 years (2001-2016) to derive growth phenology indices. We analysed individual and interactive effects of two topographical factors (aspect and elevation) on the timing of growing season in three types of grassland in the Clutha river catchment in New Zealand, to address the following questions:

1) To what degree do topographical factors (aspect and elevation) affect the timing of growing season in New Zealand's alpine grasslands? 
2) Are there any differences of the effects of aspect / elevation on the growth phenology between in alpine and in non-alpine grassland ecosystems?

\section{Methods}

\subsection{Study Area}

We chose the Clutha/Mata-Au River catchment $\left(21,400 \mathrm{~km}^{2}\right)$ in the South Island of New Zealand as our study area. Clutha catchment is New Zealand's largest rive catchment. It harbours a large proportion of alpine ecosystems in this country and conserves valuable indigenous biodiversity. Over half of Clutha catchment's land has been covered by grassland. There are three types of New Zealand's indigenous grassland in the montane areas of this catchment, and they were investigated here $\left(10,562 \mathrm{~km}^{2}, 49.4 \%\right.$ of Clutha catchment), namely Alpine grassland $\left(278 \mathrm{~km}^{2}, 1.3 \%\right.$ of Clutha catchment), Tall Tussock grassland $\left(6,406 \mathrm{~km}^{2}, 29.9 \%\right.$ of Clutha catchment), Low Producing grassland $\left(3,878 \mathrm{~km}^{2}, 18.1 \%\right.$ of Clutha catchment) (LCDB-v4.1 2015). Alpine grassland situates at the average elevation of $1,574 \mathrm{~m}$, and about $80 \%$ of this type lives in the range of $1,302 \mathrm{~m}-1,857 \mathrm{~m}$. Over $80 \%$ of Tall Tussock grassland is located at the elevation of $807 \mathrm{~m}-1,600 \mathrm{~m}$ with mean at $1,200 \mathrm{~m}$, and nearly half of this type lives above the natural treeline $(900 \mathrm{~m})$, where is defined as the alpine region in New Zealand (Wardle 2008). Low Producing grassland can be found at mean elevation of 640m, and more than $80 \%$ of this type lives between $338 \mathrm{~m}$ and $929 \mathrm{~m}$ elevation. This type is recognised as the non-alpine region in this study (Fig.1a).

\subsection{Growth phenology extraction}

Five annual growing phenological indices (Table 1) were calculated with the Moderateresolution Imaging Spectroradiometer (MODIS) imagery. We produced a time series of Normalized Difference Vegetation Index (NDVI) from 2001 to 2016 by the near-daily MODIS images at $250 \mathrm{~m}$ resolution. The 5-day maximum composite method (Fontana et al. 2008) was used to eliminate the signal noises from the raw data due to high cloud/snow coverages. We used the tool of TIMESAT 3.3 on the Matlab R2013b platform (Jonsson and Eklundh 2004) (http://web.nateko.lu.se/timesat/timesat.asp?cat=0, visited on $4^{\text {th }}$ July, 2020) to extract the five phenological indices. The Asymmetric Gaussian function in TIMESAT was selected for calculation. To better describe the growing season in the Southern Hemisphere, we created a modified day of year $\left(\mathrm{mDOY}, 1^{\text {st }} \mathrm{July}=\right.$ Day 1 of $\mathrm{mDOY} ; 30^{\text {th }}$ June in next year $=$ Day 365 of mDOY) to number the days of a year (Fig.2). The peak of season (POS) is defined as the day of highest NDVI in each modified year. The difference of NDVI between the peak NDVI of a year (P-NDVI) and the base level (the mean of the two lowest NDVIs before and after the POS of a year) is defined as the "seasonal amplitude". We used $50 \%$ of the seasonal amplitude as the threshold to decide when a growing season starts or ends: Specifically, the start of season (SOS) is the day before the POS of a year and when NDVI first reaches $50 \%$ of the seasonal 
amplitude in that year. Similarly, the end of season (EOS) is the day after POS of a year and when NDVI first drops to lower than $50 \%$ of the seasonal amplitude. The number of days between SOS and EOS is the length of season (LOS). Other parameters in TIMESAT were configured with sensitivity analyses: The cut-off point, which is used to remove spike and outliers with a median-filter method, was set to two times of standard deviation of the whole dataset (spike $=2.0$ in TIMESAT); We used twice "upper envelope" weight assignments (number of envelopes $=3$ in TIMESAT) and an adaptation (degree $=3.0$ in TIMESAT) to reduce negative bias of NDVI. With above settings, we still have a majority of pixels $(>90 \%)$ in our data left for seasonal signals extraction (Eklundha and Jönsson 2017).

\subsection{Topographical effect analysis}

The NZSoSDEM data (Columbus et al. 2011) (Fig.1b) were used to calculate aspect and elevation. This original $15 \mathrm{~m}$ resolution DEM (digital elevation model) was resampled to $250 \mathrm{~m}$ resolution in ArcGIS 10.1. Particularly, we converted aspect to be a new variable named "Southness" to quantify the degree of shade on slopes. We transformed the aspect values of 181-360 to 179- 0 , but kept the aspect values of 0-180. Therefore, the values of Southness range from north-facing (0 (N), sunny slopes) to south-facing (180 (S), shaded slopes).

The relationships between the five phenological indices (SOS, EOS, LOS, POS, P-NDVI) and the two topographic factors (Southness and Elevation) were analysed by linear regression models. In order to eliminate the effects of spatial autocorrelation which make the generalised least squares (OLS) models invalid, we chose the Simultaneous Auto-Regressive (SAR) model (Dormann et al. 2007) to calculate the relationships of the variables extracted from our spatial datasets. Three SAR model specifications (Formula 1-3) were used in this study, and which specification was suitable is determined by the Lagrange Multiplier (LM) test criteria (Elhorst 2014).

The SAR-lag model:

$$
Y=\rho W Y+X \beta+u
$$

The SAR-error model:

$$
Y=X \beta+\lambda W \varepsilon+u
$$

The SAR-sac/sarar model:

$$
\mathrm{Y}=\rho \mathrm{WY}+\mathrm{X} \beta+\lambda \mathrm{W} \varepsilon+\mathrm{u}
$$

In above formulas, Y represents the vector of response variable (one of the five phenological indices); $\mathrm{X}$ is the matrix of predictor variables (Southness, Elevation, and both); $\beta$ is the coefficient of a linear regression model; $\mathrm{W}$ is the spatial weights matrix; $\rho$ is the autoregressive coefficient for the spatial lagged dependent variable $Y ; \lambda$ is the autoregressive coefficient for the spatial weighted error term; $\varepsilon$ is a spatially dependent error term; $\mathrm{u}$ is a non-spatial error 
term. In SAR-lag model, $\lambda$ is assumed to be 0 , while in SAR-error model $\rho$ is assumed to be 0 . In SAR-sac/sarar model, $\rho$ and $\lambda$ are both non-zeros. In formula (3) the Ws for spatial lagged item $(\rho \mathrm{WY})$ and spatial error item $(\lambda \mathrm{W} \varepsilon)$ could be different, however, we used the same $\mathrm{W}$ for both items in this study.

We used an inverse-distance-weight algorithm ("dnearneigh" function in the package "spdep" on R platform (Bivand and Wong 2018)) to generate a specific spatial weights matrix (W) for each SAR model. The main idea is that: In an image, one pixel's spatial proximity to its surrounding pixels can be described by certain weights which are negatively associated with the distances of pixels (Fortin 2005). The hypothesis is that spatial autocorrelation affects within a limited distance in a spatial dataset. Instead of calculating a $\mathrm{W}$ with all pixels, we used a distance threshold to produce a specific $\mathrm{W}$ in each SAR model calculation. This threshold was determined by a semi-variogram test (Hession and Moore 2011).

In order to evaluate the capacities of topographical factors in explaining the changes of phenological indices, we used Akaike information criterion (AIC) to quantify the fitnesses of different SAR models (Kissling and Carl 2008; Maggini et al. 2006). An intercept function ( 1) was used as null hypothesis. Four functions of southness and elevation against each phenological index and for each year were assessed. The delta AIC averages were summarized in Table 4.

All the calculations including SAR model regressions, Lagrange Multiplier tests, semivariogram tests, AIC assessments were accomplished with the package "spdep" on R platform v3.5.3 (R Core Team 2020).

\section{Results}

\subsection{The correlation between aspect and growth phenology}

During our study period of time (2001-2016), the start of growing season (SOS) happened earlier on southwest-facing slopes, but later on northeast- and east-facing slopes in all three grassland types (Fig.3). The average dates of SOS were 149.9, 119.4 and 93.4 mDOY in Alpine grassland, Tall Tussock grassland and Low Producing grassland, individually (Table 2). The northeast-facing (sunny) habitats showed 3.3-7.1 days later of SOS than average in these grassland types.

The end of growing season (EOS) was detected to be later on the north- and northeast-facing slopes in Alpine grassland and Tall Tussock grassland, while EOS occurred later on the southeast-facing areas in Low Producing grassland (Fig.3). The Alpine grassland on northeast slopes (NE) exhibited approximately 29.9 days later of EOS than on southwest slopes (SW). The trend of later EOS on more northeast-facing slopes was also observed in Tall Tussock grassland, that the northeast-facing habitats showed roughly 22.0 days later of EOS than the southwest-facing ones. In contrast, Low Producing grassland presented a different spatial trend 
of EOS to the other two grassland types, that the southeast-facing Low Producing grassland showed 16.4 days later of EOS than on the northwest-facing slopes (Table 2).

Alpine grassland and Tall Tussock grassland were detected to have a longer growing season (LOS) on north-facing slopes, however shorter LOSs were found on the north-facing slopes in Low Producing grassland. Specifically, there were about 20.2 days longer of LOS on northfacing (sunny) Alpine grassland than on south-facing (shaded) side. For Tall Tussock grassland, the difference was nearly 12.3 days longer of LOS on north-facing sites. Low Producing grassland showed a reverse trend that the north-facing habitats had 11.6 days shorter of LOS.

The peak of growing season (POS) exhibited an identical pattern as EOS in the three grassland types: the POS had been reached later on northeast-facing slopes in Alpine grassland and Tall Tussock grassland, while on east-facing slopes in Low Producing grassland. The differences of POS between the latest and the earliest are 22.3, 19.5 and 14.0 days in Alpine, Tall Tussock and Low Producing grassland, individually.

Higher peak day NDVI (P-NDVI) was found on more east-facing slopes in all three grassland types. Alpine grassland showed the highest mean P-NDVI of 0.357, with 0.052 higher than the lowest mean value on west-facing slopes. Tall Tussock grassland's P-NDVI showed a difference of 0.024 between the maximum ( 0.487 on east-facing slopes) and minimum $(0.463$ on west-facing slopes). The highest P-NDVI of Low Producing grassland appeared on southeast-facing slopes with 0.029 higher than on the northwest-facing slopes.

\subsection{The correlation between elevation and growth phenology}

In all three grassland types, the start of growing season was observed to be later as elevation rises. The SOS in Alpine grassland exhibited about 8.5 days later per $100 \mathrm{~m}$ higher of elevation (Fig.4). The delay of SOS in Tall Tussock grassland were 5.2 days per $100 \mathrm{~m}$ higher on average, and the degree of delaying became higher when elevation exceeds $1,200 \mathrm{~m}$. Similarly, the delaying speed of SOS in Low Producing grassland was lower when under 1,200m of elevation (3.7 days later per 100m upwards) but higher when above this elevation ( 8.2 days later per $100 \mathrm{~m}$ upwards).

The season end was less sensitive to elevation changes, especially in Alpine grassland (Fig.4). There was a weak trend of later EOS as elevation climbs in the Alpine grassland under 1,300 $\mathrm{m}$. However, when above the elevation of $1,300 \mathrm{~m}$, EOS in Alpine grassland stayed the same at about 312-315 mDOY (Table 3). For Tall Tussock grassland, the EOS happened 4.9 days later per 100m upwards when below 1,300m elevation, and EOS also kept at 316-320 mDOY when above $1,300 \mathrm{~m}$. In Low Producing grassland the EOS was delayed by 5.8 days per $100 \mathrm{~m}$ higher of elevation when below 1,300 m, but it fixed at $320 \mathrm{mDOY}$ when above this elevation.

The length of growing season showed a strong negative correlation with elevation in the grassland above 1,300 m (Fig.4). The Alpine grassland under 1,300m showed 190.4 days of 
Topographical effects on phenology

LOS on average, and it was not sensitive to elevation changes. Nevertheless, LOS in the Alpine grassland located at $1,300-1,900 \mathrm{~m}$ showed a negative relation with elevation, that LOS decreased by 10.0 days per $100 \mathrm{~m}$ upwards. It was also observed in Tall Tussock grassland that LOS was shortened by 9.4 days per $100 \mathrm{~m}$ uphill when above $1,300 \mathrm{~m}$. At the elevation of $900-$ 1,300m, Tall Tussock grassland exhibited a constant LOS of 200.0 days. The Low Producing grassland above $1,400 \mathrm{~m}$ showed a shorter LOS of 11.8 days per $100 \mathrm{~m}$ upwards.

The peak of season was positively correlated with elevation (Fig.4). In the Alpine grassland above $1,200 \mathrm{~m}$, POS was reached by 4.4 days later per $100 \mathrm{~m}$ higher of elevation. The POS in Tall Tussock grassland was delayed dramatically by elevation (13.3 days later per 100m upwards) in low land $(400-700 \mathrm{~m})$ rather than in high land above $700 \mathrm{~m}$ (3.5 days later per $100 \mathrm{~m}$ upwards). The changing rate of POS in Low producing grassland was 5.3 days later per $100 \mathrm{~m}$ higher on average.

P-NDVI was negatively related to elevation (Fig.4). The changing speed of P-NDVI were $0.033,-0.023$ and -0.012 per $100 \mathrm{~m}$ upwards in Alpine grassland, Tall Tussock grassland and Low Producing grassland. Oscillations in the changing rates of P-NDVI were observed in the low land of Tall Tussock grassland and Low Producing grassland.

\subsection{Inter-annual relationships between topography and phenology}

Very weak relationships (less than \pm 1.0 days per 10-degree-south) between SOS and southness (aspect) were observed in all three grasslands through 16 years (Fig.5 (I) a). Instead, EOS was highly correlated with southness in Alpine grassland and Tall Tussock grassland. The EOS in Alpine grassland showed 1.0-2.0 days earlier per 10-degree-south in most of the 16 years, except in year 2011 with 2.9 days earlier per 10-degree-south. In Tall Tussock grassland, the sensitivities of EOS to aspect fluctuated among 0.5-1.5 days earlier per 10-degree-south through the years. Weak positive correlations between EOS and southness had been observed in Low Producing grassland during 2001-2016. LOS constantly showed negative relations in Alpine grassland and Tall Tussock grassland in all the study period, with 1.4 and 0.8 days shorter per 10-degree-south on average; In contrast, LOS in Low Producing grassland exhibited positive correlations with southness with a mean of 0.7 days longer per 10-degree-south. The Alpine grassland and Tall Tussock grassland showed the same trend of earlier POS on southfacing slopes. On average, POS was reached in these two grassland types by 1.1 days earlier per 10-degree-south in the study period. However, POS in Low Producing grassland showed no response to aspect in all the years (Fig.5 (I) b). No more than \pm 0.001 P-NDVI per 10-degreesouth of changes were detected during the 16 years (Fig.5 (I) c). The average changing rates were $+0.0004,-0.0005$ and 0.0000 of P-NDVI per 10-degree-south in Alpine grassland, Tall Tussock grassland and Low Producing grassland

All the five annual phenological indices were more sensitive to elevation changes during 20022016 (Fig.5 (II)). In Alpine grassland, SOS exhibited strong correlations with elevation by 5.5- 
10.3 days later per 100m upwards in these years, while the delaying trends of SOS were weaker in Tall Tussock grassland (3.8-6.3 days later per 100m upwards) and Low Producing grassland (1.3-4.7 days later per 100m upwards) (Fig.5 (II) a). On the other hand, the EOS in Alpine grassland showed no relationship with elevation during the years, but weak later trends of EOS along elevation had been detected in Tall Tussock grassland and Low Producing grassland. As a result, the LOS in Alpine grassland was negatively related to elevation through years (7.4 days shorter per $100 \mathrm{~m}$ upwards on average). Weaker negative correlations between LOS and elevation were found in Tall Tussock grassland (3.0 days shorter per 100m upwards on average) and in Low Producing grassland (0.9 days shorter per 100m upwards on average). POS in all three grassland types were always delayed by elevation rise during the years (Fig.5 (II) b), with average delays of 3.4 days in Alpine grassland, 3.6 days in Tall Tussock grassland and 5.1 days in Low Producing grassland per 100m higher. P-NDVI constantly showed a negative relation with elevation in the 16 years (Fig.5 (II) c), with means of $-0.033,-0.023,-0.012$ per $100 \mathrm{~m}$ upwards in three grassland types respectively.

\subsection{Interactive topographical effects on timing of growing seasons}

We displayed the distributions of five annual phenological on an aspect-elevation coordinate to illustrate whether interactive topographical effects existed in our study (Fig.6). It showed that SOS was mainly correlated to elevation only in grasslands (Fig.6a), except the SOS in the grassland under 1,400m showing 1.0-5.0 days later on east-facing slopes than on west-facing slopes at the same elevation.

Though elevation effect was still dominant, EOS exhibited a stronger correlation with aspect than did SOS. For the alpine species of this study (including all of Alpine grassland and the Tall Tussock grassland above the $900 \mathrm{~m}$ treeline), there was a circle of EOS distribution in north direction (Aspect $0(\mathrm{~N})$, Fig.6b) at 1,400-1,500m elevation, where EOS occurred later on northfacing slopes than on other directions. Another circle can be seen on northwest slopes under $500 \mathrm{~m}$ elevation in Low Producing grassland, indicating EOS on northwest slopes appeared earlier than other regions.

The POS in Alpine grassland was correlated to both aspect and elevation (Fig.6c). POS generally exhibited a delaying trend as elevation increases, meanwhile the grassland on eastfacing slopes reached POS later than on west-facing slopes at the same elevation. Differently, POS in Tall Tussock grassland and Low Producing grassland was delayed by elevation in all aspects.

All grassland types had shorter LOS as elevation rises, while aspect modified LOS's changing rates (Fig.6d). Above 1,200m, the Alpine grassland on north-facing slopes had the longest LOS. The Tall Tussock grassland above $1,200 \mathrm{~m}$ showed decreasing LOS along elevation in all directions, while under $1,200 \mathrm{~m}$ LOS was shorter on north-facing habitats. There was a concave of LOS in the contour of Low Producing grassland at 400m elevation, indicating that when 
above $400 \mathrm{~m}$, longer LOS was detected on north-facing slopes and at higher elevations, whereas when below $400 \mathrm{~m}$, the situation reversed.

Generally, P-NDVI in three grassland types decreased as elevation rises (Fig.6e). P-NDVI was strongly correlated with elevation in both alpine and non-alpine ecosystems. Above $1,000 \mathrm{~m}$ elevation, P-NDVI declined at the same rate along elevation in all aspects. While in the Tall Tussock grassland under $1,000 \mathrm{~m}$ and in the Low Producing grassland under $800 \mathrm{~m}$, P-NDVI was higher on south-facing slopes.

The delta AICs of SAR models showed that the additive and interactive formulas are more effective than any single variable formulas when explaining the changes of the five annual phenological indices (Table 4). The single variable function of elevation ("elev") against SOS contributed the most in decreases of AIC, showing that the changes of SOS can be well estimated only by elevation. Aspect ("south") was a more descriptive variable for EOS changes in Alpine grassland, while in Low Producing grassland, elevation was a more effective factor in explaining EOS's variation. In Tall Tussock grassland, the two-variable formulas were more suitable to describe EOS changes than single variable formulas. Aspect and elevation were both substantial in explaining LOS changes in three grassland types. The two-variable formulas can also effectively estimate POS changes in Alpine grassland and Tall Tussock grassland, but elevation was the only descriptive variable for POS in Low Producing grassland. Elevation can explain all the variations of P-NDVI in three grassland types.

Overall, the delta AICs of models (Table 4) demonstrates the fact that SOS was mainly correlated to elevation, while EOS was likely controlled by aspect in alpine habitats but by elevation in non-alpine habitats. Elevation showed a better capacity to describe LOS in alpine habitats than in non-alpine ecosystems. The additive functions decreased the similar AIC as the interactive functions did, which indicated that elevation and aspect had independent correlations with the five phenological indices.

\section{Discussion}

\subsection{Alpine ecosystems' phenological responses to topography}

This study showed that the timing of growing season in New Zealand's alpine ecosystems was sensitive to topographical factors. Aspect and elevation exhibited considerable effects on phenology in different ways. Elevation mainly affects the start of season, while aspect mostly modifies the end of season. Lower air temperature at high elevation regions might be the cause for the delay of growing season start. However, the mechanism that how elevation "controls" the growth season start was not deciphered in this research. For aspect's modification on growth phenology, that longer growing season was observed on north-facing slopes, a rational explanation could be that the sunny habitats have more exposure to sunshine therefore have more temperature accumulation (Zhang et al. 2004; Fontana et al. 2008). Researches also 
showed that air temperature does not directly affect plants' phenology, and complex interactions exist between environmental factors which limit the resources of plant growth (Jolly et al. 2005). Temperature and radiation have been proven to be substantial controllers of phenology, but at high elevation regions there are more uncertainties in their effects on phenology due to other associated factors such as water stress (Hwang et al. 2011). Our result, that aspect and elevation affected different phenological indices, indicates that alpine ecosystems are subject to different environmental restrictions at different growing stages.

Because mountainous areas offer diverse environmental resources and montane plants well adapt to the harsh but variant environmental conditions, alpine ecosystems may not have to migrate upwards mountains to find suitable climates. Therefore, contemporary climate change is not expected to exhaust alpine plants' ecological niches. The topographical heterogeneity in mountains can provide a wide range of microclimatic conditions on the horizontal direction which produces unique ecological niches (Bickford et al. 2011). Microclimate at a small scale can provide "refugia" for montane plants to escape from the large-scale climate change by a short migration (Opedal et al. 2015). The alpine grassland's plasticity could also lessen the impacts of climate change by adjusting their phenology activities (Frei et al. 2014). Thus, alpine plants have chance to survive under current global climate change due to the high heterogeneity in their montane habitats.

\subsection{The difference of topographical effects in alpine and in non-alpine ecosystems}

The topographical factors exhibited different effects on the timing of growing season in alpine and non-alpine ecosystems. The growing phenology of alpine plants showed a closer association with topographical factors, especially when the habitats situated above $1,200 \mathrm{~m}$ elevation. In this study, the Alpine grassland type represented alpine ecosystems and the Low producing grassland type represents non-alpine ecosystems. Tall Tussock grassland is a transition type which includes both alpine and non-alpine components. The distribution of phenological indices in the aspect \& elevation coordinate (Fig.6) showed distinct patterns in Alpine and Low producing grassland, while showed a combined pattern in Tall Tussock grassland.

The growing phenology in alpine ecosystems was more sensitive to topographical effects than in non-alpine ecosystems. The start of season shifted more days in alpine plants than in nonalpine plants when elevation rises. The end of season in alpine ecosystems performed more variations along aspect than did in non-alpine ecosystems. The similar situation was also detected in the length of season and P-NDVI that they were more responsive to topographical changes in alpine habitats. It would be due to the high diversity of topography in mountainous land than in low land.

Furthermore, some of the phenological indices in non-alpine grassland showed opposite responses to aspect changes as in alpine grassland. For example, later end of season and later 
Topographical effects on phenology

361

362

363

364

365

366

367

368

369

370

371

372

373

374

375

376

377

378

379

380

381

382

383

384

385

386

387

388

389

season peak in non-alpine grassland were observed more on shaded slopes, and the length of season tended to be shorter on sunny slopes. Water deficiency on the sunny (north-facing) slopes could be the reason for the shorter growing periods in non-alpine ecosystems at low elevations.

\section{Conclusion}

The timing of growing season in New Zealand's natural grassland showed variant correlations with topographical factors (aspect and elevation). The start of growing season was strongly correlated with elevation, showing 7.5, 5.1 and 3.7 days delay per 100m higher the elevation in Alpine grassland, Tall Tussock grassland and Low Producing grassland. The end of season advanced by 1.7 and 1.3 days per 10-degree-south in Alpine grassland and Tall Tussock grassland, while it was delayed by 0.3 days per10-degree-south in Low Producing grassland. In the alpine ecosystems (all Alpine grassland and the Tall Tussock grassland above treeline), elevation strongly correlated to the start of season, while aspect highly affected the end of season. So, the length of growing season had a strong negative relation with elevation and it tended to be longer on north-facing (sunny) slopes in alpine ecosystems. The season peak delayed as elevation rises and it appeared earlier on shaded slopes. The higher elevation showed the lower peak NDVI in all grassland types. These topographical effects are more pronounced at high elevations above $1,300 \mathrm{~m}$.

In contrast, the non-alpine ecosystems' (all Low Producing grassland and the Tall Tussock grassland below treeline) end of season was less responsive to aspect changes, but it was delayed as elevation climbs. The start of season in non-alpine ecosystems showed a weak relationship with elevation. Topography had weak effects on the length of season in non-alpine habitats. Weak responses to topographical changes were observed in the peak of season and the peak day NDVI in all non-alpine grassland.

Overall, aspect and elevation are important factors in explaining the changes of growth phenology in alpine ecosystems, while elevation can explain most of the changes in the timing of growing season in non-alpine ecosystems. Aspect and elevation independently affect the timing of growing season in New Zealand's natural grassland. 


\section{Declarations}

391

392

393

394

395

396

397

398

399

400

401

402

403

404

405

406

407

408

409

410

411

412

413

414

415

416

417

418

419

420

421

422

423

424

425

426

427

428

429

430

Funding: This study is supported by Miss E. L. Hellaby Indigenous Grasslands Research Trust granted to Xiaobin Hua in 2016.

Conflicts of interest/Competing interests: None.

Ethics approval: Not applicable.

Consent to participate: Not applicable.

Consent for publication: Not applicable.

Availability of data and material: The MODIS NDVI data that support the findings of this study are available from the co-author Pascal Sirguey (pascal.sirguey@otago.ac.nz) upon reasonable request. The climate data (VCSN) that support the findings of this study are openly available in NIWA at https://data.niwa.co.nz.

Code availability: The code that support the findings of this study is available from the corresponding author Xiaobin Hua (Xiaobin.hua@lincoln.ac.nz) upon reasonable request.

Authors' contributions: RO and $\mathrm{XH}$ conceived the study. $\mathrm{XH}$ developed and conducted all analyses and wrote a first draft of the manuscript. PS collated and prepared all MODIS data and provided guidance on the time series analyses. All authors contributed to writing the final manuscript.

\section{References}

Barnard DM, Barnard HR, Molotch NP (2017) Topoclimate effects on growing season length and montane conifer growth in complex terrain. Environmental Research Letters 12 (6). doi:10.1088/1748-9326/aa6da8

Bickford CP, Hunt JE, Heenan PB (2011) Microclimate characteristics of alpine bluff ecosystems of New Zealand's South Island, and implications for plant growth. New Zealand Journal of Ecology 35 (3):273-279

Bivand RS, Wong DW (2018) Comparing implementations of global and local indicators of spatial association. Test 27 (3):716-748

Chen IC, Hill JK, Ohlemuller R, Roy DB, Thomas CD (2011) Rapid Range Shifts of Species Associated with High Levels of Climate Warming. Science 333 (6045):1024-1026. doi:10.1126/science.1206432

Columbus J, Sirguey P, Tenzer R (2011) A free, fully assessed 15-m DEM for New Zealand, vol 66.

Dormann CF, McPherson JM, Araujo MB, Bivand R, Bolliger J, Carl G, Davies RG, Hirzel A, Jetz W, Kissling WD, Kuhn I, Ohlemuller R, Peres-Neto PR, Reineking B, Schroder B, Schurr FM, Wilson R (2007) Methods to account for spatial autocorrelation in the analysis of species distributional data: a review. Ecography 30 (5):609-628. doi:10.1111/j.2007.09067590.05171.x

Dufour A, Gadallah F, Wagner HH, Guisan A, Buttler A (2006) Plant species richness and environmental heterogeneity in a mountain landscape: effects of variability and spatial configuration. Ecography 29 (4):573-584. doi:doi:10.1111/j.0906-7590.2006.04605.x

Eklundha L, Jönsson P (2017) TIMESAT 3.3 with Seasonal Trend Decomposition and Parallel Processing Software Manual. Lund University, 
Elhorst JP (2014) Spatial econometrics: from cross-sectional data to spatial panels, vol 479. Springer, Fontana F, Rixen C, Jonas T, Aberegg G, Wunderle S (2008) Alpine grassland phenology as seen in AVHRR, VEGETATION, and MODIS NDVI time series - a comparison with in situ measurements. Sensors 8 (4):2833-2853. doi:10.3390/s8042833

Fortin M-Je (2005) Spatial analysis : a guide for ecologists. Cambridge University Press, New York

Frei ER, Ghazoul J, Matter P, Heggli M, Pluess AR (2014) Plant population differentiation and climate change: responses of grassland species along an elevational gradient. Global Change Biology 20 (2):441-455. doi:10.1111/gcb.12403

Gottfried M, Pauli H, Futschik A, Akhalkatsi M, Barancok P, Alonso JLB, Coldea G, Dick J, Erschbamer B, Calzado MRF, Kazakis G, Krajci J, Larsson P, Mallaun M, Michelsen O, Moiseev D, Moiseev P, Molau U, Merzouki A, Nagy L, Nakhutsrishvili G, Pedersen B, Pelino G, Puscas M, Rossi G, Stanisci A, Theurillat JP, Tomaselli M, Villar L, Vittoz P, Vogiatzakis I, Grabherr G (2012) Continent-wide response of mountain vegetation to climate change. Nature Climate Change 2 (2):111-115. doi:10.1038/nclimate1329

Hession SL, Moore N (2011) A spatial regression analysis of the influence of topography on monthly rainfall in East Africa. International Journal of Climatology 31 (10):1440-1456. doi:10.1002/joc. 2174

Hwang T, Song CH, Vose JM, Band LE (2011) Topography-mediated controls on local vegetation phenology estimated from MODIS vegetation index. Landscape Ecology 26 (4):541-556. doi:10.1007/s10980-011-9580-8

Jolly WM, Dobbertin M, Zimmermann NE, Reichstein M (2005) Divergent vegetation growth responses to the 2003 heat wave in the Swiss Alps. Geophysical Research Letters 32 (18). doi: $10.1029 / 2005 \mathrm{gl} 1023252$

Jonsson P, Eklundh L (2004) TIMESAT - a program for analyzing time-series of satellite sensor data. Computers \& Geosciences 30 (8):833-845. doi:10.1016/j.cageo.2004.05.006

Kissling WD, Carl G (2008) Spatial autocorrelation and the selection of simultaneous autoregressive models. Global Ecology and Biogeography 17 (1):59-71. doi:doi:10.1111/j.14668238.2007.00334.x

LCDB-v4.1 (2015) Land Cover Database version 4.1. The Land Resource Information Systems Portal and scinfo.org.nz. https://lris.scinfo.org.nz/layer/423-lcdb-v41-land-cover-database-version41-mainland-new-zealand/. Accessed 16/06 2017

Lenoir J, Gegout JC, Marquet PA, de Ruffray P, Brisse H (2008) A significant upward shift in plant species optimum elevation during the 20th century. Science 320 (5884):1768-1771. doi:10.1126/science.1156831

Maggini R, Lehmann A, Zimmermann NE, Guisan A (2006) Improving generalized regression analysis for the spatial prediction of forest communities. Journal of Biogeography 33 (10):1729-1749. doi:doi:10.1111/j.1365-2699.2006.01465.x

Moser L, Fonti P, Buntgen U, Esper J, Luterbacher J, Franzen J, Frank D (2010) Timing and duration of European larch growing season along altitudinal gradients in the Swiss Alps. Tree Physiology 30 (2):225-233. doi:10.1093/treephys/tpp108

Opedal ØH, Armbruster WS, Graae BJ (2015) Linking small-scale topography with microclimate, plant species diversity and intra-specific trait variation in an alpine landscape. Plant Ecology \& Diversity 8 (3):305-315. doi:10.1080/17550874.2014.987330

R Core Team (2020) R: A language and environment for statistical computing. R Foundation for Statistical Computing, Vienna, Austria

Redpath TAN, Sirguey P, Cullen NJ (2018) Repeat mapping of snow depth across an alpine catchment with RPAS photogrammetry. Cryosphere 12 (11):3477-3497. doi:10.5194/tc-123477-2018

Rogora M, Frate L, Carranza ML, Freppaz M, Stanisci A, Bertani I, Bottarin R, Brambilla A, Canullo R, Carbognani M, Cerrato C, Chelli S, Cremonese E, Cutini M, Di Musciano M, Erschbamer B, Godone D, Iocchi M, Isabellon M, Magnani A, Mazzola L, Morra di Cella U, Pauli H, Petey M, Petriccione B, Porro F, Psenner R, Rossetti G, Scotti A, Sommaruga R, Tappeiner U, Theurillat JP, Tomaselli M, Viglietti D, Viterbi R, Vittoz P, Winkler M, Matteucci G (2018) Assessment of climate change effects on mountain ecosystems through a cross-site 
analysis in the Alps and Apennines. Science of The Total Environment 624:1429-1442. doi:https://doi.org/10.1016/j.scitotenv.2017.12.155

Scherrer D, Korner C (2010) Infra-red thermometry of alpine landscapes challenges climatic warming projections. Global Change Biology 16 (9):2602-2613. doi:10.1111/j.13652486.2009.02122.x

Spasojevic MJ, Bowman WD, Humphries HC, Seastedt TR, Suding KN (2013) Changes in alpine vegetation over 21 years: Are patterns across a heterogeneous landscape consistent with predictions? Ecosphere 4 (9). doi:10.1890/es13-00133.1

Telwala Y, Brook BW, Manish K, Pandit MK (2013) Climate-Induced Elevational Range Shifts and Increase in Plant Species Richness in a Himalayan Biodiversity Epicentre. Plos One 8 (2). doi:10.1371/journal.pone.0057103

Tennant CJ, Harpold AA, Lohse KA, Godsey SE, Crosby BT, Larsen LG, Brooks PD, Van Kirk RW, Glenn NF (2017) Regional sensitivities of seasonal snowpack to elevation, aspect, and vegetation cover in western North America. Water Resources Research 53 (8):6908-6926. doi:doi:10.1002/2016WR019374

Testolin R, Attorre F, Jiménez-Alfaro B (2020) Global distribution and bioclimatic characterization of alpine biomes. Ecography 43 (6):779-788. doi:https://doi.org/10.1111/ecog.05012

Thompson JA, Paull DJ (2017) Assessing spatial and temporal patterns in land surface phenology for the Australian Alps (2000-2014). Remote Sensing of Environment 199:1-13. doi:https://doi.org/10.1016/j.rse.2017.06.032

Verrall B, Pickering CM (2020) Alpine vegetation in the context of climate change: A global review of past research and future directions. Science of The Total Environment 748:141344. doi:https://doi.org/10.1016/j.scitotenv.2020.141344

Wardle P (2008) New Zealand forest to alpine transitions in global context. Arctic Antarctic and Alpine Research 40 (1):240-249. doi:10.1657/1523-0430(06-066)

You JL, Qin XP, Ranjitkar S, Lougheed SC, Wang MC, Zhou W, Ouyang DX, Zhou Y, Xu JC, Zhang WJ, Wang YG, Yang J, Song ZP (2018) Response to climate change of montane herbaceous plants in the genus Rhodiola predicted by ecological niche modelling. Scientific Reports 8. doi:10.1038/s41598-018-24360-9

Zhang XY, Friedl MA, Schaaf CB, Strahler AH (2004) Climate controls on vegetation phenological patterns in northern mid- and high latitudes inferred from MODIS data. Global Change Biology 10 (7):1133-1145. doi:10.1111/j.1529-8817.2003.00784.x 


\section{$518 \quad$ Tables}

519 Table 1 The five annual growth phenology indices investigated in this study (see Methods 520 and Fig.2 for details of how these indices are calculated).

\begin{tabular}{|c|c|c|c|}
\hline No & Index & Abbreviation & Definition \\
\hline 1 & Start of season & SOS & $\begin{array}{l}\text { The day of the season on which NDVI exceeds } 50 \% \text { of the } \\
\text { season peak NDVI for the first time. }\end{array}$ \\
\hline 2 & End of season & EOS & $\begin{array}{l}\text { The day of the season on which NDVI drops to } 50 \% \text { of the } \\
\text { season peak NDVI after the peak day of season. }\end{array}$ \\
\hline 3 & Length of season & LOS & The number of days between start and end of the season. \\
\hline 4 & Peak Day of season & POS & $\begin{array}{l}\text { The day of the season on which NDVI reaches its peak of this } \\
\text { growing season. }\end{array}$ \\
\hline 5 & Peak NDVI & P-NDVI & The fitted NDVI maximum of a growing season \\
\hline
\end{tabular}

Table 2 The 16-year averages of five phenological indices on aspects. Aspect values (0-360) are divided into 8 bands to summarize phenological indices' averages. Each aspect band has a 45-degree range with the central aspect value as the band's name: For instance, North (N, 0 (360)) covers the range of 337.5-360 degree plus 0-22.5 degree.

\begin{tabular}{|c|c|c|c|c|c|c|c|c|c|c|}
\hline \multirow[t]{3}{*}{ Index } & \multirow[t]{3}{*}{ Grassland type } & \multicolumn{9}{|c|}{ Aspect (Deg.) and Direction } \\
\hline & & 225 & 270 & 315 & $0(360)$ & 45 & 90 & 135 & 180 & Mean \\
\hline & & SW & W & NW & $\mathrm{N}$ & $\mathrm{NE}$ & $\mathrm{E}$ & SE & $\mathrm{S}$ & \\
\hline \multirow{3}{*}{$\begin{array}{l}\text { Start of } \\
\text { season }\end{array}$} & Alpine & 144.3 & 144.3 & 148.3 & 153.7 & 153.2 & 153.2 & 153.3 & 148.9 & 149.9 \\
\hline & Tall Tussock & 113.6 & 113.8 & 119.3 & 124.4 & 126.5 & 124.0 & 118.8 & 116.4 & 119.4 \\
\hline & $\begin{array}{l}\text { Low } \\
\text { Producing }\end{array}$ & 87.9 & 88.1 & 89.9 & 93.9 & 99.2 & 100.1 & 95.6 & 90.6 & 93.4 \\
\hline \multirow{3}{*}{$\begin{array}{l}\text { End of } \\
\text { season }\end{array}$} & Alpine & 297.5 & 306.1 & 319.6 & 324.6 & 327.4 & 323.7 & 309.5 & 299.6 & 313.6 \\
\hline & Tall Tussock & 301.6 & 310.4 & 318.4 & 323.3 & 324.0 & 320.5 & 312.5 & 303.0 & 314.1 \\
\hline & $\begin{array}{l}\text { Low } \\
\text { Producing }\end{array}$ & 274.5 & 270.9 & 265.4 & 269.3 & 279.9 & 282.8 & 281.8 & 277.7 & 275.3 \\
\hline \multirow{3}{*}{$\begin{array}{l}\text { Length of } \\
\text { season }\end{array}$} & Alpine & 153.2 & 161.8 & 171.3 & 170.9 & 174.2 & 170.5 & 156.1 & 150.7 & 163.7 \\
\hline & Tall Tussock & 188.0 & 196.6 & 199.1 & 198.9 & 197.5 & 196.5 & 193.7 & 186.6 & 194.7 \\
\hline & $\begin{array}{l}\text { Low } \\
\text { Producing }\end{array}$ & 186.5 & 182.8 & 175.4 & 175.4 & 180.8 & 182.7 & 186.2 & 187.0 & 181.9 \\
\hline \multirow{3}{*}{$\begin{array}{l}\text { Peak of } \\
\text { season }\end{array}$} & Alpine & 221.4 & 226.5 & 236.6 & 241.8 & 243.7 & 241.5 & 232.9 & 224.9 & 233.8 \\
\hline & Tall Tussock & 209.7 & 215.0 & 222.1 & 227.6 & 229.2 & 225.6 & 218.4 & 211.9 & 219.7 \\
\hline & $\begin{array}{l}\text { Low } \\
\text { Producing }\end{array}$ & 179.7 & 177.8 & 175.7 & 179.8 & 188.0 & 189.7 & 187.2 & 182.9 & 182.7 \\
\hline \multirow{3}{*}{$\begin{array}{l}\text { Peak day } \\
\text { NDVI }\end{array}$} & Alpine & 0.305 & 0.305 & 0.329 & 0.326 & 0.346 & 0.357 & 0.327 & 0.333 & 0.331 \\
\hline & Tall Tussock & 0.464 & 0.463 & 0.463 & 0.472 & 0.483 & 0.487 & 0.485 & 0.473 & 0.474 \\
\hline & $\begin{array}{l}\text { Low } \\
\text { Producing }\end{array}$ & 0.581 & 0.578 & 0.575 & 0.583 & 0.596 & 0.600 & 0.604 & 0.599 & 0.589 \\
\hline
\end{tabular}


527 Table 3 The 16-year averages of five phenological indices on elevation bands. Units: Start of 528 season (mDOY), End of season (mDOY), Length of season (days), Peak of season (mDOY),

529 Peak day NDVI (unitless). The ' $\mathrm{n} / \mathrm{a}$ ' means there is no data (distribution) at this elevation range.

\begin{tabular}{|c|c|c|c|c|c|c|c|c|c|c|}
\hline \multirow[t]{2}{*}{ Index } & \multirow{2}{*}{$\begin{array}{l}\text { Grassland } \\
\text { type }\end{array}$} & \multicolumn{9}{|c|}{ Elevation (m) } \\
\hline & & $0-300$ & $301-600$ & $601-900$ & $\begin{array}{l}901- \\
1200\end{array}$ & $\begin{array}{r}1201- \\
1500\end{array}$ & $\begin{array}{r}1501- \\
1800\end{array}$ & $\begin{array}{r}1801- \\
2100\end{array}$ & $\begin{array}{r}2101- \\
2400\end{array}$ & Mean \\
\hline \multirow{3}{*}{$\begin{array}{l}\text { Start of } \\
\text { season }\end{array}$} & Alpine & $\mathrm{n} / \mathrm{a}$ & $\mathrm{n} / \mathrm{a}$ & $\mathrm{n} / \mathrm{a}$ & 118.6 & 135.4 & 156.7 & 175.7 & 182.8 & 149.9 \\
\hline & Tussock & 82.3 & 89.5 & 105.5 & 108.6 & 121.9 & 146.6 & 169.2 & 191.5 & 119.4 \\
\hline & $\begin{array}{l}\text { Low } \\
\text { Producing } \\
\end{array}$ & 74.3 & 84.3 & 98.3 & 106.9 & 113.4 & 138.2 & $\mathrm{n} / \mathrm{a}$ & $\mathrm{n} / \mathrm{a}$ & 93.4 \\
\hline \multirow{3}{*}{$\begin{array}{l}\text { End of } \\
\text { season }\end{array}$} & Alpine & $\mathrm{n} / \mathrm{a}$ & $\mathrm{n} / \mathrm{a}$ & $\mathrm{n} / \mathrm{a}$ & 308.9 & 315.3 & 313.3 & 311.8 & 319.8 & 313.6 \\
\hline & Tussock & 265.6 & 273.8 & 303.7 & 310.6 & 321.2 & 320.6 & 316.2 & 316.4 & 314.1 \\
\hline & $\begin{array}{l}\text { Low } \\
\text { Producing }\end{array}$ & 252.5 & 260.4 & 282.4 & 296.2 & 321.2 & 317.7 & $\mathrm{n} / \mathrm{a}$ & $\mathrm{n} / \mathrm{a}$ & 275.3 \\
\hline \multirow{3}{*}{$\begin{array}{l}\text { Length } \\
\text { of } \\
\text { season }\end{array}$} & Alpine & $\mathrm{n} / \mathrm{a}$ & $\mathrm{n} / \mathrm{a}$ & $\mathrm{n} / \mathrm{a}$ & 190.4 & 179.9 & 156.6 & 136.1 & 137.0 & 163.7 \\
\hline & Tussock & 183.3 & 184.3 & 198.2 & 202.1 & 199.3 & 174.0 & 147.0 & 124.8 & 194.7 \\
\hline & $\begin{array}{l}\text { Low } \\
\text { Producing }\end{array}$ & 178.1 & 176.2 & 184.1 & 189.2 & 207.7 & 179.4 & $\mathrm{n} / \mathrm{a}$ & $\mathrm{n} / \mathrm{a}$ & 181.9 \\
\hline \multirow{3}{*}{$\begin{array}{l}\text { Peak of } \\
\text { season }\end{array}$} & Alpine & $\mathrm{n} / \mathrm{a}$ & $\mathrm{n} / \mathrm{a}$ & $\mathrm{n} / \mathrm{a}$ & 218.1 & 228.3 & 236.6 & 243.8 & 251.1 & 233.8 \\
\hline & Tussock & 170.0 & 179.8 & 207.5 & 212.9 & 224.9 & 236.3 & 244.9 & 254.5 & 219.7 \\
\hline & $\begin{array}{l}\text { Low } \\
\text { Producing }\end{array}$ & 159.8 & 169.8 & 189.0 & 201.8 & 221.8 & 230.3 & $\mathrm{n} / \mathrm{a}$ & $\mathrm{n} / \mathrm{a}$ & 182.7 \\
\hline \multirow{3}{*}{$\begin{array}{l}\text { Peak day } \\
\text { NDVI }\end{array}$} & Alpine & $\mathrm{n} / \mathrm{a}$ & $\mathrm{n} / \mathrm{a}$ & $\mathrm{n} / \mathrm{a}$ & 0.446 & 0.384 & 0.309 & 0.219 & 0.173 & 0.331 \\
\hline & Tussock & 0.474 & 0.514 & 0.533 & 0.497 & 0.458 & 0.412 & 0.333 & 0.215 & 0.474 \\
\hline & $\begin{array}{l}\text { Low } \\
\text { Producing }\end{array}$ & 0.590 & 0.619 & 0.586 & 0.530 & 0.444 & 0.349 & $\mathrm{n} / \mathrm{a}$ & $\mathrm{n} / \mathrm{a}$ & 0.589 \\
\hline
\end{tabular}


532 Table 4 Delta AICs ( $\triangle$ AIC) of the spatial autoregressive (SAR) models simulating the five 533 phenological indices against aspect and elevation. Four functions including single variable, 534 additive variables and multiplied variables are tested under null hypothesis (see Methods). 535 Lower $\triangle$ AIC indicates better capability of a function to explain the changes of a phenological 536 index. Abbreviations of variable names: SOS - Start of season, EOS — End of season, LOS 537 Length of season, POS — Peak of season, P-NDVI—Peak day NDVI, south—southness, elev538 elevation.

\begin{tabular}{lrrrrrrrrrr}
\hline \multirow{2}{*}{ Models } & \multicolumn{2}{c}{ SOS } & \multicolumn{2}{c}{ EOS } & \multicolumn{2}{c}{ LOS } & \multicolumn{2}{c}{ POS } & \multicolumn{3}{c}{ P-NDVI } \\
& \multicolumn{1}{c}{ AIC } & $(\%)$ & \multicolumn{1}{c}{$\Delta$ AIC } & $(\%)$ & $\Delta$ AIC & $(\%)$ & $\Delta$ AIC & $(\%)$ & $\Delta$ AIC & $(\%)$ \\
\hline Alpine & & & & & & & & & & \\
$\sim 1$ & 0 & 0.00 & 0 & 0.00 & 0 & 0.00 & 0 & 0.00 & 0 & 0.00 \\
$\sim$ south & 9 & 0.03 & 697 & 2.01 & 247 & 0.65 & 435 & 1.35 & 2 & 0.02 \\
$\sim$ elev & 1984 & 5.63 & 91 & 0.26 & 863 & 2.26 & 608 & 1.89 & 2284 & 27.65 \\
$\sim$ south+elev & 2016 & 5.72 & 742 & 2.14 & 1325 & 3.47 & 1034 & 3.22 & 2379 & 28.81 \\
$\sim$ south*elev & 2066 & 5.86 & 773 & 2.23 & 1338 & 3.50 & 1109 & 3.45 & 2393 & 28.97 \\
Tall Tussock & & & & & & & & & & \\
$\sim 1$ & 0 & 0.00 & 0 & 0.00 & 0 & 0.00 & 0 & 0.00 & 0 & 0.00 \\
$\sim$ south & 78 & 0.18 & 508 & 1.26 & 169 & 0.38 & 426 & 1.08 & 7 & 0.07 \\
$\sim$ elev & 1775 & 4.18 & 655 & 1.62 & 410 & 0.92 & 2080 & 5.29 & 2643 & 24.25 \\
$\sim$ south+elev & 1849 & 4.36 & 1254 & 3.10 & 605 & 1.36 & 2625 & 6.68 & 2676 & 24.55 \\
$\sim$ south*elev & 1943 & 4.58 & 1373 & 3.40 & 773 & 1.74 & 2653 & 6.75 & 2722 & 24.98 \\
Low Producing & & & & & & & & & & \\
$\sim 1$ & 0 & 0.00 & 0 & 0.00 & 0 & 0.00 & 0 & 0.00 & 0 & 0.00 \\
$\sim$ south & 46 & 0.13 & 18 & 0.05 & 77 & 0.20 & -28 & -0.08 & 10 & 0.10 \\
$\sim$ elev & 652 & 1.81 & 601 & 1.55 & 77 & 0.20 & 955 & 2.64 & 623 & 5.88 \\
$\sim$ south+elev & 705 & 1.95 & 633 & 1.63 & 159 & 0.41 & 975 & 2.70 & 629 & 5.94 \\
$\sim$ souht*elev & 719 & 1.99 & 656 & 1.69 & 169 & 0.43 & 993 & 2.75 & 650 & 6.14 \\
\hline
\end{tabular}




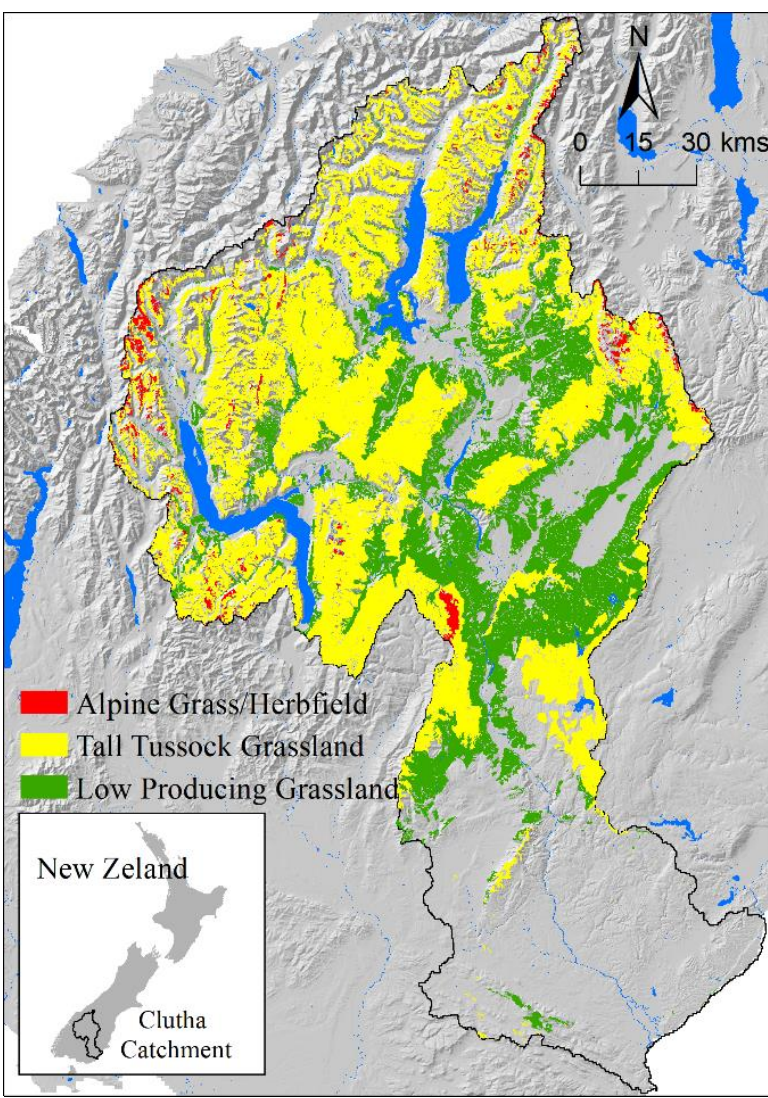

(a)

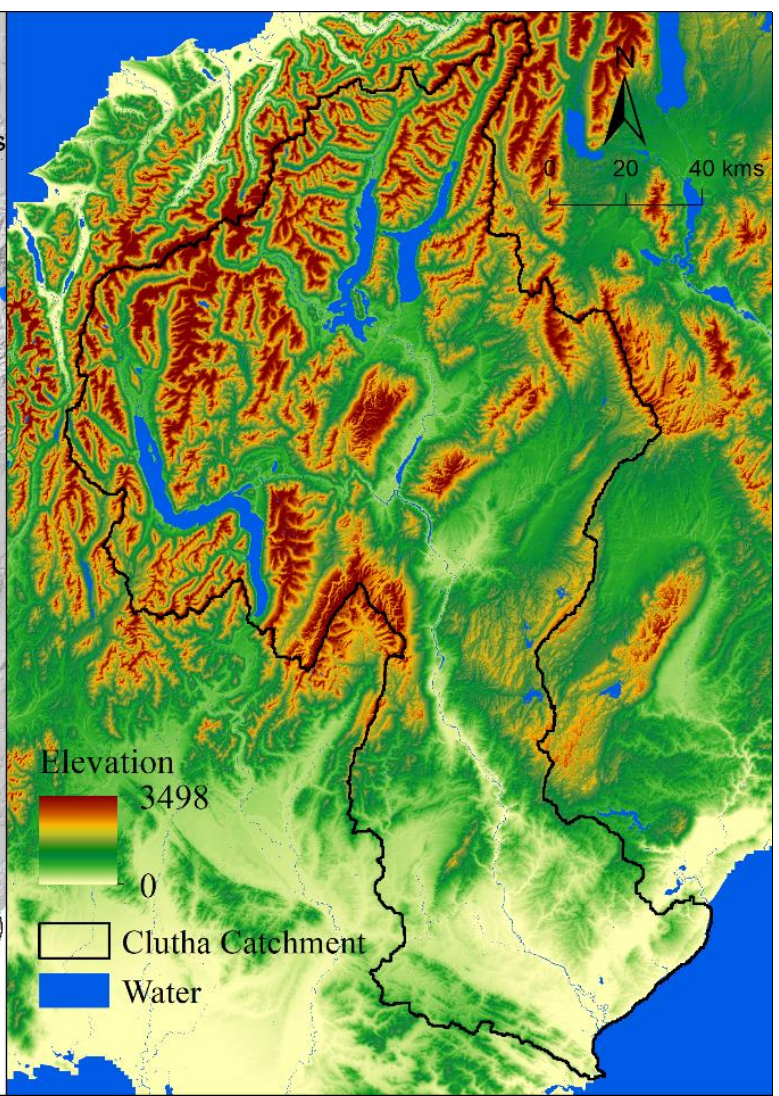

(b)

543 Fig.1 Study area: (a) The Clutha/Mata-Au river catchment, New Zealand with the spatial 544 distribution of the three types of grasslands (Alpine Grass/Herbfield, Tall Tussock and Low 545 producing) investigated in this study; (b) Average altitudes of the three grassland types derived 546 from the NZ land cover database v4.1 (LCDB-v4.1 2015) were $1574 \mathrm{~m}$ a.s.1. $(S D=225 \mathrm{~m})$ for 547 Alpine, $1197 \mathrm{~m}(S D=311 \mathrm{~m})$ for Tall Tussock and $641 \mathrm{~m}(S D=229 \mathrm{~m})$ for Low-Producing 548 grasslands (Columbus et al. 2011). 


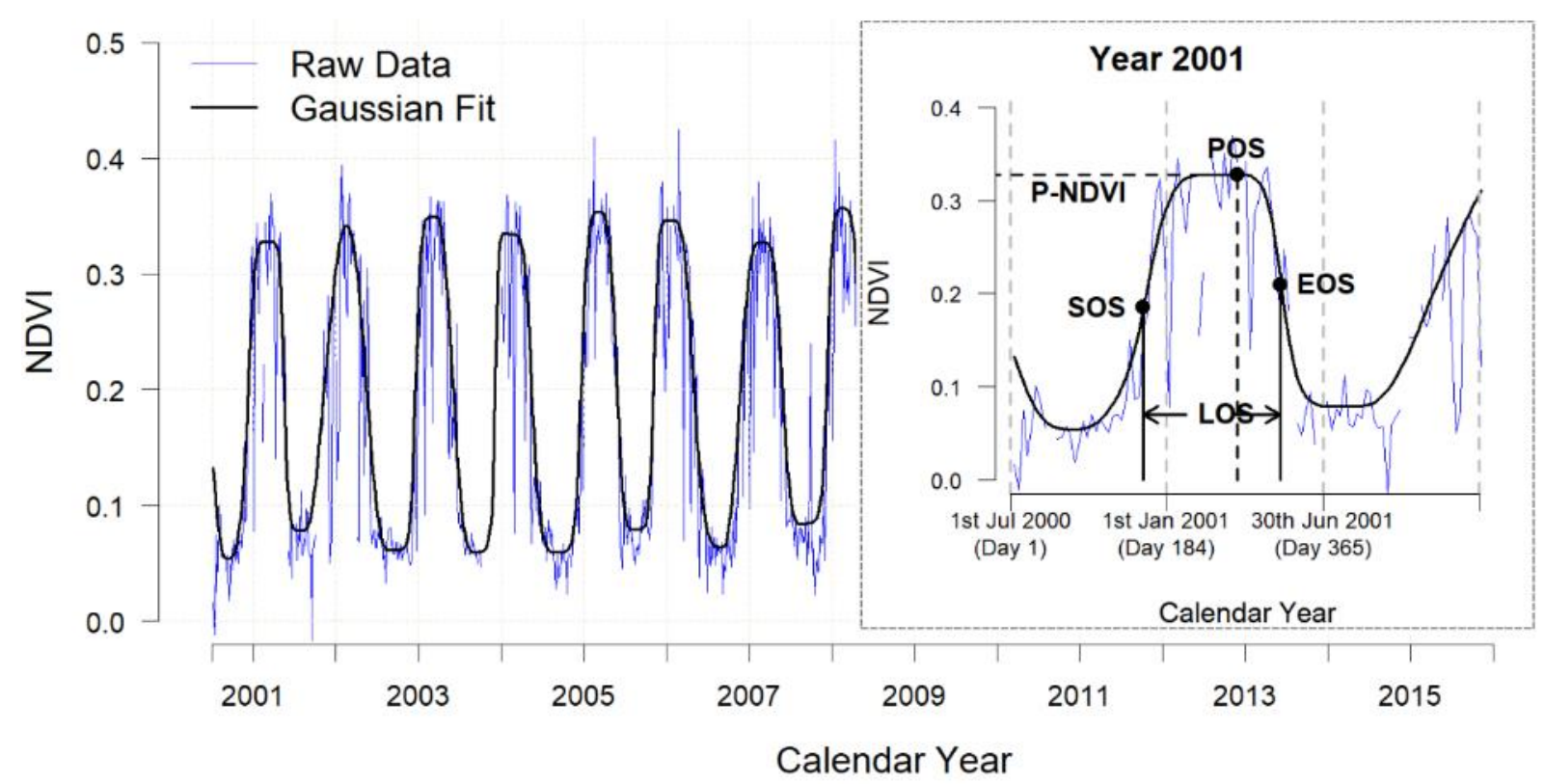

551 Fig.2 The MODIS NDVI 2001-2016 time series for an example pixel and derivation of the five growth phenology indices (SOS = start of season, EOS = end of season, LOS = length of season, $\mathrm{POS}=$ peak of season, P-NDVI = peak day NDVI). In the time series, the blue colour indicates raw data and the black line shows the fitted curve derived by TIMESAT (see Methods for details). We used a modified day-of-year (mDOY) to describe growth phenology in the South Hemisphere, so that a growing year starts on 1st July one year and ends on 30th June the year after (mDOY $1=1$ st July, mDOY $365=30$ st June). 

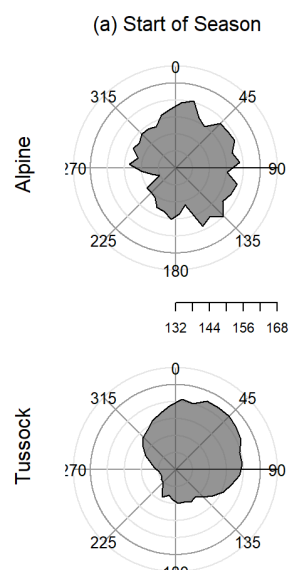

다대 | 1
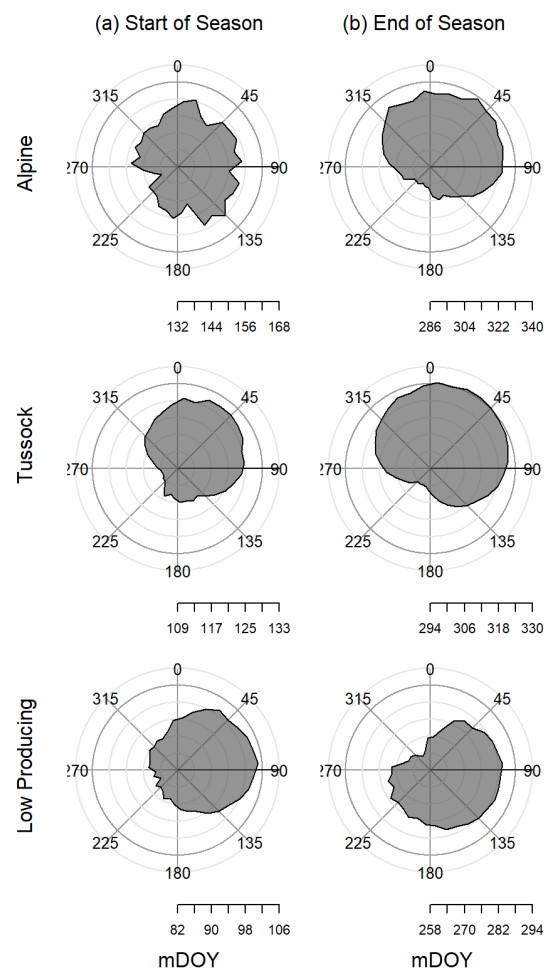

$\begin{array}{lllll}286 & 304 & 322 & 340\end{array}$
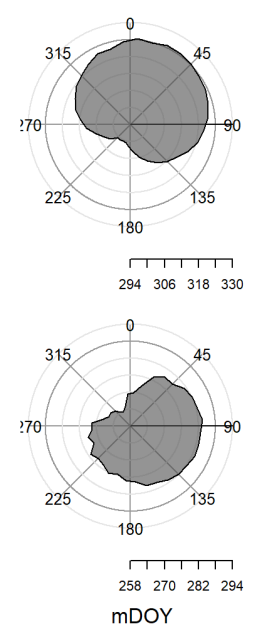

Fig.3 The 16-year averages of five growth phenological indices (a-e) in relation to aspect in the study area. For each aspect circle, 0 represents direct north, 90 represents direct east, 180 represents direct south and 270 represents direct west. The shade in each panel illustrates the 16-year average value of each phenological index at each 10-deg of aspect in each grassland
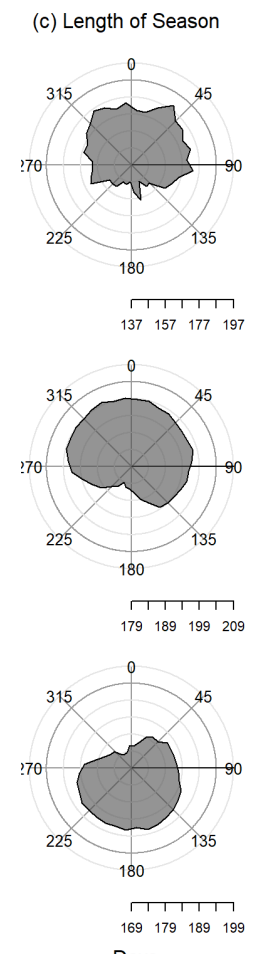

Days
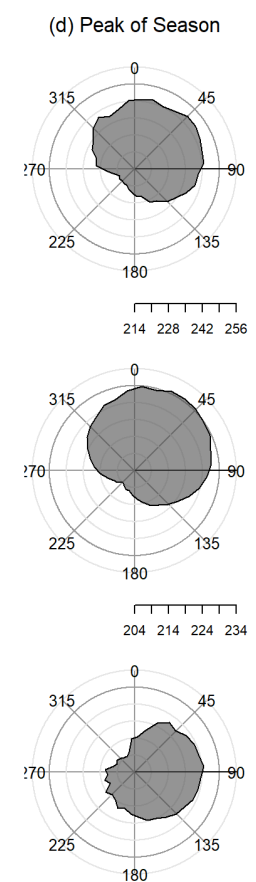

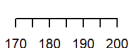
mDOY

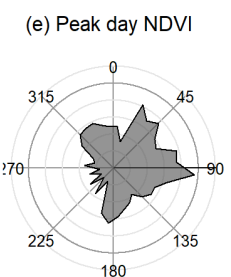

\begin{tabular}{c|cc} 
군. \\
0.28 & 0.34 & 0.4
\end{tabular}
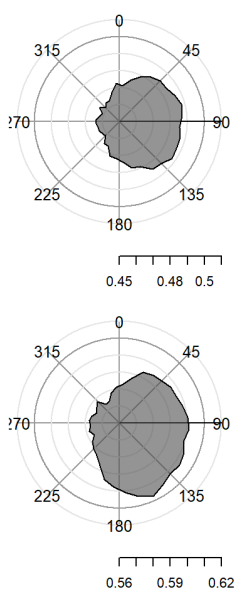
NDVI
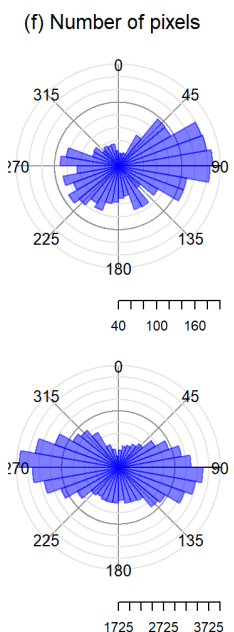

तापापापा $1725 \quad 2725 \quad 3725$

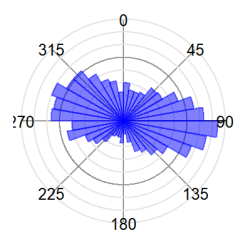

\begin{tabular}{cl|l} 
ता \\
1018 & $1618 \quad 2218$
\end{tabular} Counts 
(a) Start of Season
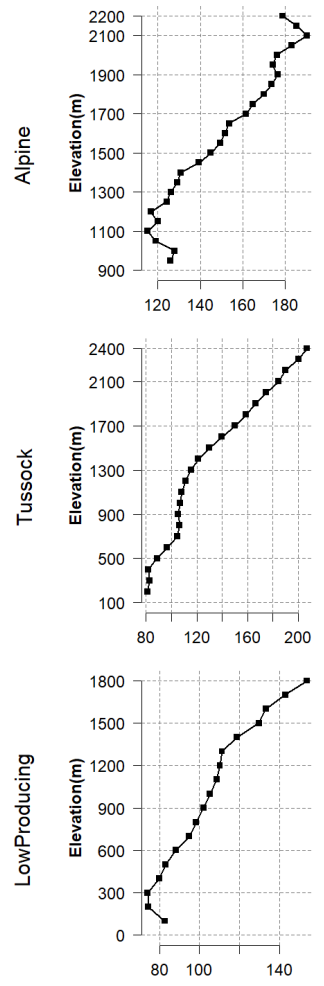

mDOY (b) End of Season
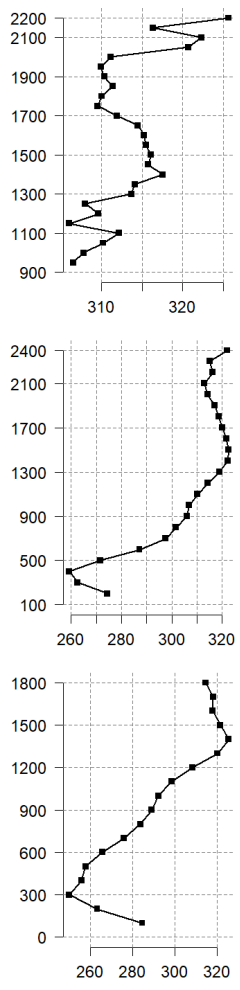

mDOY (c) Length of Season
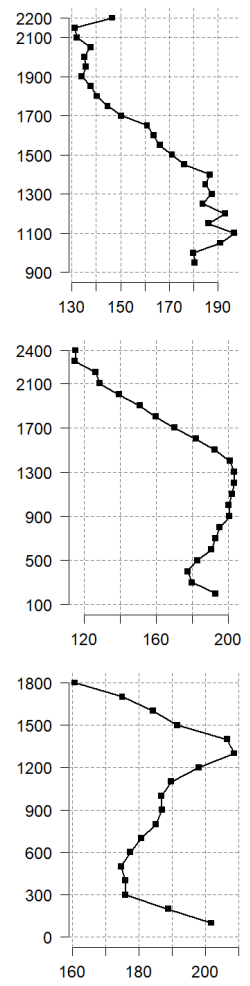

Days (d) Peak of Season
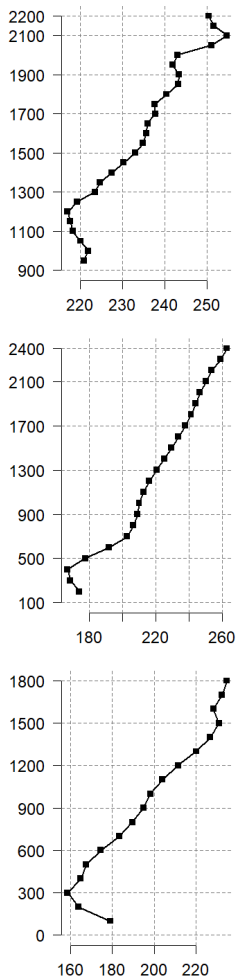

$\mathrm{mDOY}$ (e) Peak day NDVI
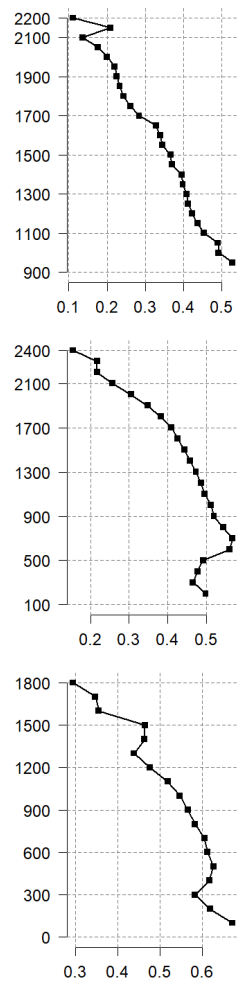

NDVI (f) Number of pixels
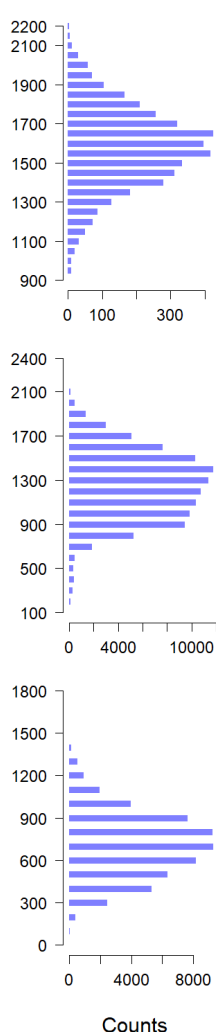

Fig. 4 The 16-year average of five growth phenological indices (a-e) along the elevation gradient in the study area.. mDOY $=$ modified day of year $\left(1=1^{\text {st }}\right.$ July; see Methods $)$. The total number of pixels in each $100 \mathrm{~m}$ elevation band is shown in panels (f). 
Southness (I)
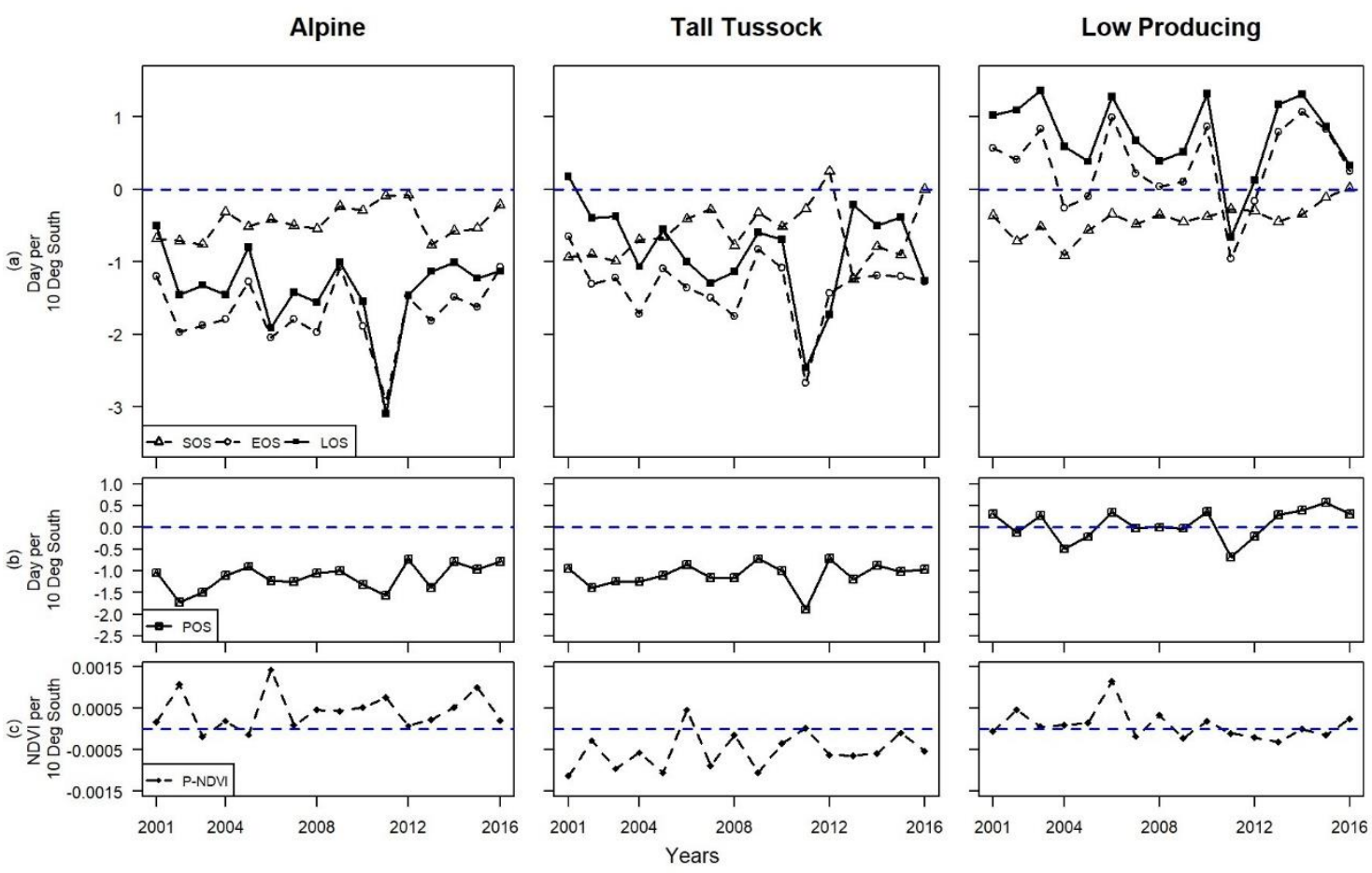

Elevation (II)

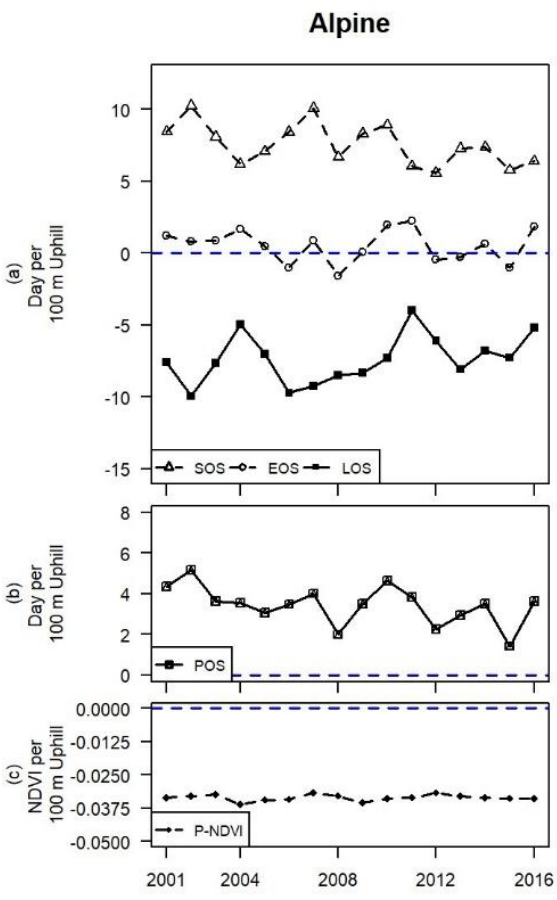

Tall Tussock
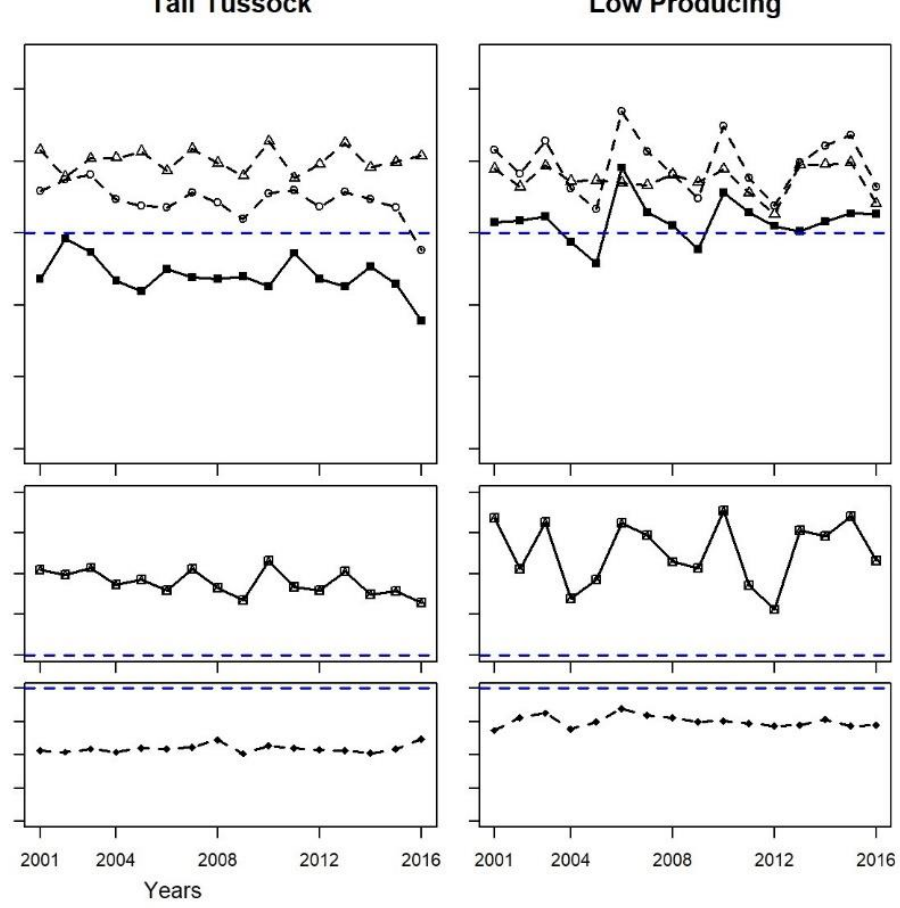

Fig. 5 The strength of the relationship between phenology and (I) aspect and (II) elevation for each year (2001-2016) and grassland type. The strength of the relationship between the five phenological indices (a-c) and aspect/elevation is expressed as the slope of linear SAR model index aspect/slope. Positive values (above blue line) indicate later start, end, peak of season; a longer season and higher NDVI on the peak day (see Methods for details). SOS = start of season, EOS = end of season, $\mathrm{LOS}=$ length of season, $\mathrm{POS}=$ peak of season, $\mathrm{P}-\mathrm{NDVI}=$ peak day NDVI. 
(a) Start
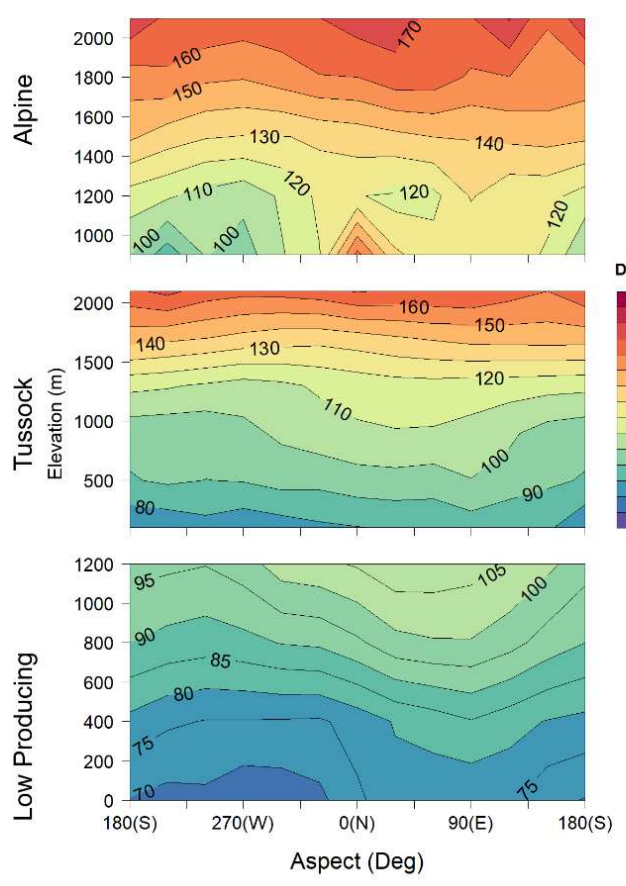

(c) Peak
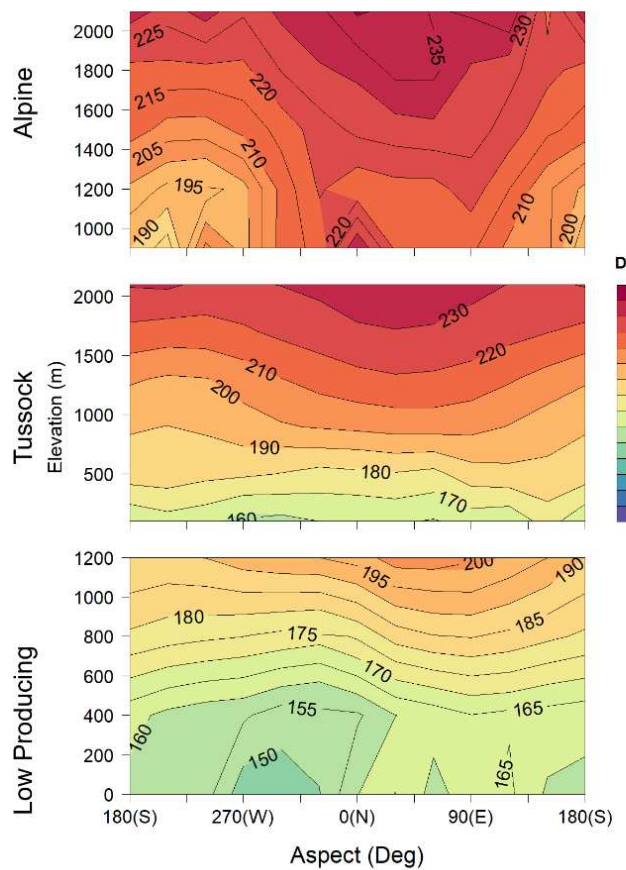

(b) End
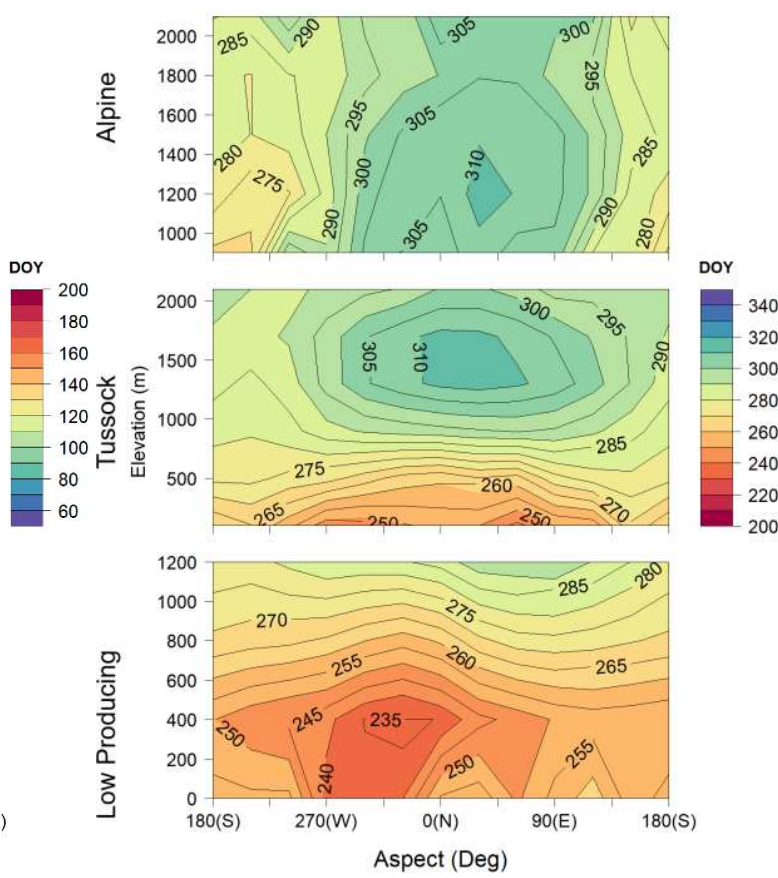

(d) Length
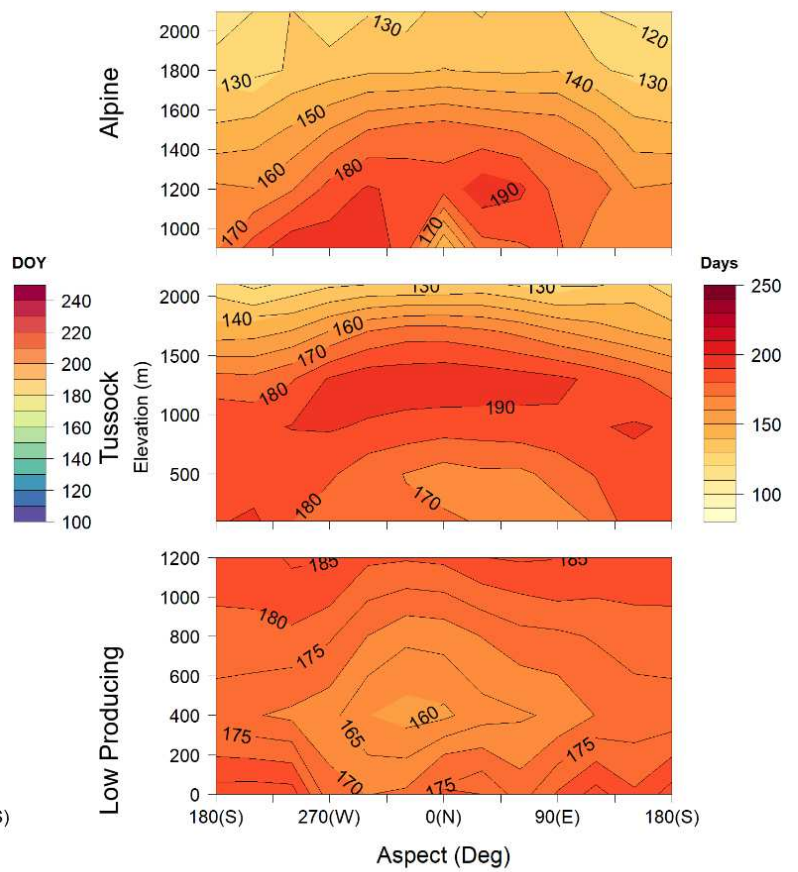
(e) P.NDVI
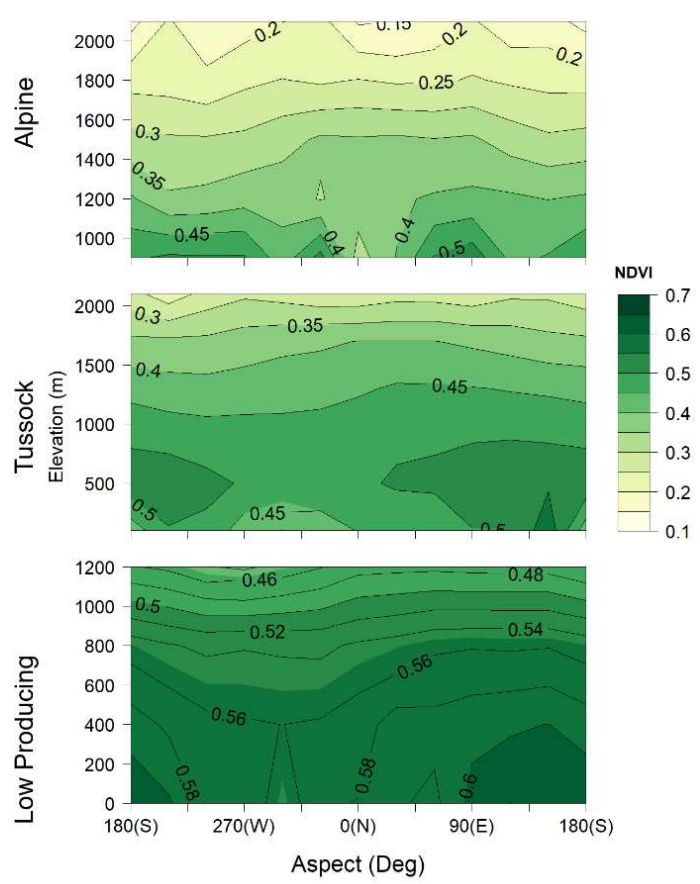

Fig.6 The interaction effects of aspect and elevation on the five phenological indices (a-e) Pixels were assigned to bins in aspect-elevation space and 16-yr averages for each index were calculated for each bin. Bins of similar values were connected with contour lines. Abbreviations: (a) Start = start of season, (b) End = end of season, (c) Peak = peak of season, (d) Length = length of season, (f) P-NDVI = peak day NDVI. 